\title{
THE KNOWLEDGE OF PREGNANT WOMEN ABOUT PRE- ECLAMPSIA AT THE TAROGONG PUBLIC HEALTH CENTER, GARUT REGENCY
}

\author{
Rizky Ayu Gardelia ${ }^{1}$, Tetti Solehati ${ }^{2}$, Lilis Mamuroh ${ }^{3}$ \\ ${ }^{1,2,3}$ Faculty of Nursing, University of Padjadjaran \\ Correspondance: tetti.solehati@unpad.ac.id
}

\begin{abstract}
The Maternal Mortality Rate (MMR) in Indonesia is still high, one of the causes is pre-eclampsia. Tarogong Garut is a health center with a high occurrence of preeclampsia and it increases annually, 34\% in 2016 increased to $51 \%$ in 2017 . The knowledge of pregnant women about preeclampsia may be one of the causes to the increased risk of preeclampsia, but there is still limited information available on the knowledge of pregnant women about preeclampsia. This study aimed to discover the knowledge of pregnant women about preeclampsia. This type of research was descriptive quantitative with a sample of 83 pregnant women. The sample was selected by the total sample technique. Data analysis used was univariate analysis. The study was conducted at the Tarogong Health Centre in March-July 2018. The instruments used were questionnaires. The results of the study showed that the knowledge of pregnant women about pre-eclampsia is still lacking in all aspects of preeclampsia knowledge, especially in aspects of signs and symptoms. In conclusion, the knowledge of pregnant women about preeclampsia is still lacking. Effective health education programs and methods are needed about preeclampsia for pregnant women, especially in Tarogong Garut.
\end{abstract}

Keywords: Knowledge, Pregnant women, Pre-eclampsia.

\section{INTRODUCTION}

The cause of Maternal Mortality Rate (MMR) in Indonesia is $28 \%$ bleeding, $24 \%$ preeclampsia, $11 \%$ infection, 5\% post-partum, and 5\% abortion. The Indonesian Maternal Mortality Rate (MMR) in 2016 was 305,000 per 100,000 live births (MOH, 2016).

West Java MMR in 2017 was 997,000 per 100,000 (Health Profile of West Java Province, 2017). One of the districts with high MMR is Garut Regency. Garut MMR in 2017 was 51 cases (Profile of Garut District Health Office, 2017). The incidence of MMR is difficult to reduce due to several factors called 4 Too, namely too young, too old, giving birth too often, having too many children, and 3 late, that is, late in using the facility, getting late for help, late in recognizing the danger signs of pregnancy and birth (Maryunani, 2015).

Pre-eclampsia is a disease characterized by increased blood pressure, proteinuria, edema during the third trimester up to 48 hours after the post-partum period. Pre-eclampsia is commonly known as pregnancy-induced hypertension (PIH) (Maryunani, 2013).

Tarogong Public Health Center 2016 data showed an increase in cases of pre-eclampsia amounting to 30 people and in 2017 there were 47 people. Data from the Garut District 
Rizky Ayu Gardelia: The Knowledge of Pregnant Women about Pre-Eclampsia

Health Office show in 2017 at Tarogong Health Center, 16 pregnant women who examined urine protein, and 8 of them were positive for urine protein. These results indicate that there is still a high occurrence of pre-eclampsia in the community health center.

According to Dewi, I A (2017) risk factors that might cause pre-eclampsia were age of mothers were less than 20 years old and more than 35 years old, mothers with hypertension, obesity, close pregnancy distance, multiple pregnancies, poor nutritional status, mothers with infection and maternal characteristics such as level of education, work and knowledge. Pregnant women with low knowledge may influence the behavior of early detection in pregnancy. This is in correlation with Perdania's research (2013, in Ambarwati, W.; 2017) stating that pre-eclampsia can be caused by risk factors such as age, occupation, ANC examination, knowledge, and history of previous hypertension.

According to Hidayah, N.R (2016) who conducted research at the Pekauman health center on 64 pregnant women showed that different levels of education affected the understanding of information so that the received information was different. The importance of knowledge was also explained in Damayanti's research, E (2010), that pregnant women with good knowledge influenced women's decision making to prevent or overcome problems, including pregnancy problems.

Based on the interview results regarding pre-eclampsia knowledge in 10 pregnant women in the Tarogong Community Health Center work area, there were 8 respondents who did not know pre-eclampsia, what were the signs of pre-eclampsia and prevention of pre-eclampsia and 2 respondents had good knowledge about pre-eclampsia. According to the observations at the Tarogong Community Health Center, health workers provided services for pregnant women and health education about the signs and dangers of pregnancy, but many pregnant women did not know the danger signs of pregnancy. This study aims to examine the knowledge of pregnant women about pre-eclampsia.

\section{METHODS}

This type of research was quantitative descriptive. Data collection was carried out in JuneJuly 2018 at Tarogong Health Center, Garut Regency. The sample in this study was 83 pregnant women selected with a total sampling technique. 
The instrument used in this study was a questionnaire that was aimed to determine the knowledge of pregnant women consisting of 5 aspects, namely understanding, predisposing factors, symptoms, impact, and prevention efforts of pre-eclampsia. Questionnaires were tested for validity test content. The number of questions was 15 questions. Data collection began with informed consent.

\section{RESULTS}

Table 1 Characteristics of pregnant women

\begin{tabular}{lll}
\hline Characteristic & Population & $\%$ \\
\hline Age & 65 & 78.3 \\
$\quad<35$ years & 18 & 21.7 \\
$>35$ years & & \\
& & \\
\hline Last Education & 5 & 6.0 \\
Elementary School & 57 & 68.7 \\
Junior High School & 21 & 25.3 \\
Senior High School & & \\
& & \\
\hline Job & 8 & 9.6 \\
Yes & 75 & 90.4 \\
No &
\end{tabular}

Table 1 shows that most respondents $65(78.3 \%)$ were $<35$ years old, went to junior high school 57 respondents $(68.7 \%)$, and 75 respondents $(90.4 \%)$ were housewives. 
Table 2 Knowledge Level of Pregnant Women $(\mathbf{N}=83)$

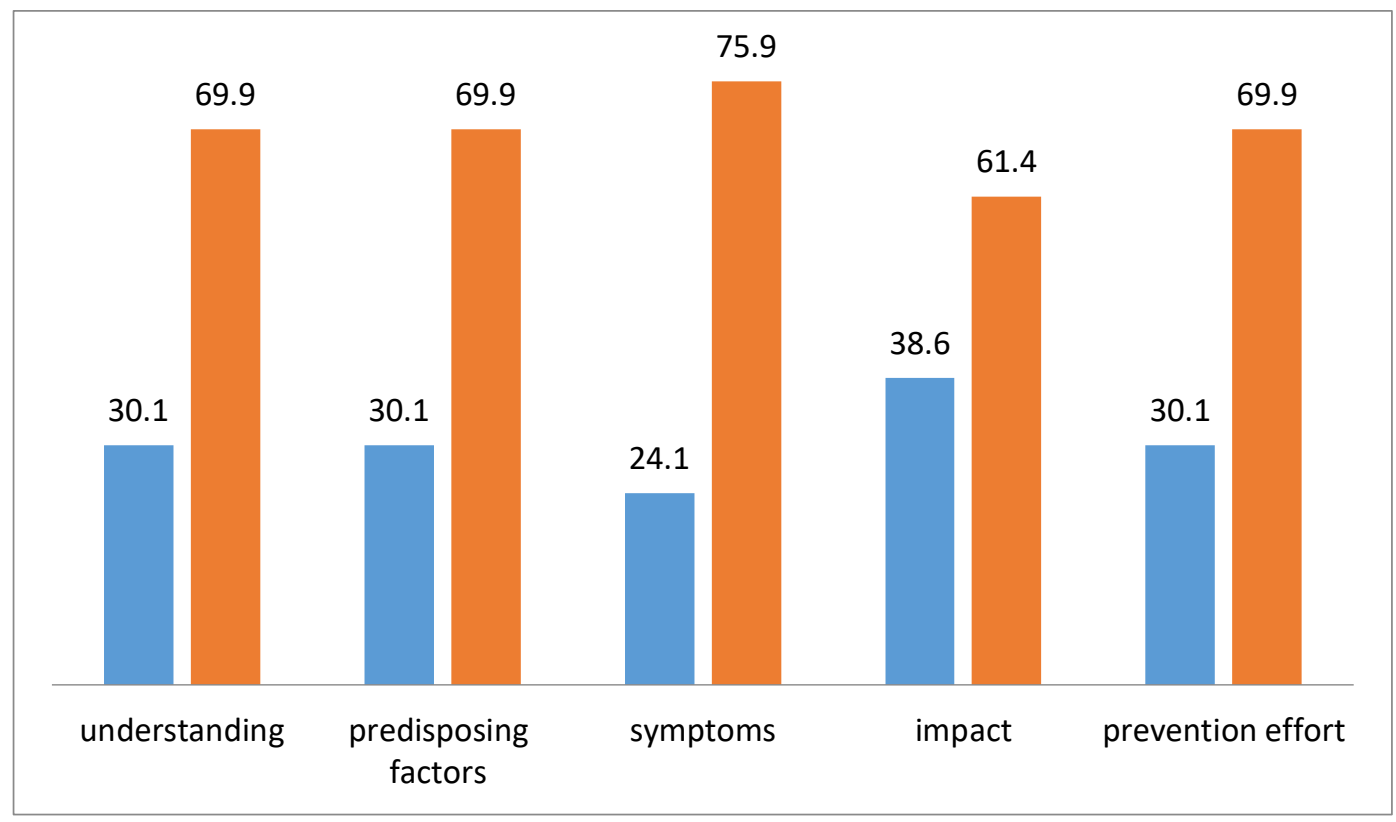

Blue:

Know

Orange:

Do

not know

Based on table 2, it could be seen that most respondents $(69.9 \%)$ did not know about the understanding of pre-eclampsia, 69.9\% of respondents did not know about predisposing factors for preeclampsia, $75.9 \%$ of respondents did not know about the signs and symptoms of preeclampsia, $61.4 \%$ of respondents did not know about the impact of preeclampsia, and $69.9 \%$ of respondents did not know about the efforts to prevent preeclampsia.

\section{DISCUSSION}

Knowledge is an important domain for the formation of one's actions. From experiences and researches, it was discovered that behavior is based on knowledge (Notoadmodjo, 2010). Factors that influence knowledge according to (Notoadmodjo, 2010) are internal and external factors. Internal factors include education, age, and work. External factors include economy, information, and environment.

The higher level of one's education affects the level of knowledge about health, pregnant women who have a high level of education may have good health knowledge (Cahyono 2009 in Perdania 2013) According to Wawan and Dewi (2011) in Setiani (2015), the level of 
education needs to be supervised to support one's health and quality of life. From the results of the study, it found that lack of pre-eclampsia knowledge was most likely because most respondents had a junior high school education level of $57(68.7 \%)$

Another factor was age, according to Cahyono (2009) in Perdania (2013) age influence how one's capture information and mindset. The older the age affects the experience so that the better knowledge will be gained. From the results of the study, it was found that the majority of respondents (78.3\%) amounting to 65 women aged between 16-35 years were very helpful in facilitating the provision of information regarding pre-eclampsia.

According to Nursalam (2004) in Perdania 2013, someone who has a job has more access to information and experience. Work makes someone interact more and get information from friends or the mass media. Information increases knowledge. The results of the study showed that the number of respondents that did not work was 75 people $(90.4 \%)$ therefore the possibility of receiving information about pre-eclampsia is limited.

\section{CONCLUSION}

Based on the results of the research conducted at the Tarogong Health Center in Garut Regency, it was concluded that the pregnant women knowledge on pre-eclampsia was still lacking. It is necessary to perform an effective information dissemination method for pregnant women with low formal education levels and not working.

\section{INTRODUCTION}

Arikunto, S. (2013). Prosedur Penelitian Suatu Pendekatan Praktik. Jakarta: Rineka Cipta. Amelia, R., Ariadi, A., \& Azmi, S. (2016). Perbedaan Berat Lahir Bayi Pasien Preeklampsia Berat/Eklampsia Early dan Late Onset di RSUP Dr. M. Djamil Padang. Jurnal Kesehatan Andalas, 5(1),135-138.

Cunningham, et al, 2014. Obstetri. Jakarta: EGC.

Damayanti, E., \& Nur, A. (2010). Hubungan Tingkat Pengetahuan Perempuan hamil Tentang Resiko Tinggi Kehamilan dengan Kepatuhan Kunjungan Antenatal Care di RSUD Pandan Arang Boyolali.3(4),174-182. 
Rizky Ayu Gardelia: The Knowledge of Pregnant Women about Pre-Eclampsia

Dewi, R. G. A. I. (2017). Pengaruh Kemampuan Perempuan hamil dalam Melakukan Deteksi Dini Resiko Preeklamsia Terhadap Paritas, Pengetahuan Dan Keterpaparan Informasi. Medical Technology and Public Health Journal, 1(1),27-34.

Hutahean, Serri. 2013. Perawatan Antenatal. Jakarta: Salemba Medika.

Kozier, Barbara. 2010. Buku Ajar Fundamental Keperawatan: Konsep, Proses \& Praktik. Jakarta: EGC.

Linggardini, K., \& Aprilina, H. D. (2016). Pengaruh Pendidikan Kesehatan Pada Perempuan hamil Terhadap Pengetahuan Tentang Preeklamsia di Wilayah Kerja Puskesmas Sokaraja I. MEDISAINS, 14(2),10-15.

Lowdermilk, L.D \& Perry, E.S \& Cashion, Kity.2013.Keperawatan Maternitas.Singapore:Salemba Medika.

Manuaba. 2010. Ilmu Kebidanan Penyakit Kandungan dan KB. Jakarta: EGC.

Maryunani, Anik.2015. Kegawat Daruratan Maternal dan Neonatal Terpadu.Jakarta: TIM.

Maryunani, Anik. 2013 . Asuhan Kegawatdaruratan Maternal \& Neonatal. Jakarta: Trans Info Medika.

Notoadmodjo. S. 2010a. Metedologi Penelitian Kesehatan. Jakarta: Rineka Cipta.

Notoadmodjo. S. 2007. Promosi Kesehatan Dan Ilmu Perilaku. Jakarta: Rineka Cipta.

Notoadmodjo. S. 2010. Ilmu Perilaku Kesehatan. Jakarta: Rineka Cipta.

Notoadmodjo. S. 2012. Promosi Kesehatan Perilaku Kesehatan. Jakarta: Rineka Cipta.

Nurliawati, E. (2015). Hubungan Antara Preeklampsia Berat Dengan Bayi Berat Lahir Rendah (BBLR) di RSU Dr. Soekardjo Kota Tasikmalaya Tahun 2013. Jurnal Kesehatan Bakti Tunas Husada, 12(1), 22-27.

Nursal, D. G. A., Tamela, P., \& Fitrayeni, F. (2017). Faktor Risiko Kejadian Preeklampsia pada Perempuan hamil di Rsup Dr. M. Djamil Padang Tahun 2014. Jurnal Kesehatan Masyarakat Andalas, 10(1), 38-44.

Nursalam.2008. Konsep dan Penerapan Metedologi Penelitian Ilmu Keperawatan Pedoman Skripsi, Tesis dan Penelitian Keperawatan.Jakarta: Salemba Medika.

Prawirohardjo, S. 2014. Ilmu Kebidanan. Jakarta: PT. Bina Pustaka.

Radjamuda, N., \& Montolalu, A. (2014). Faktor-Faktor Risiko Yang Berhubungan Dengan Kejadian Hipertensi Pada Perempuan hamil Di Poli Klinik Obs-Gin Rumah Sakit Jiwa Prof. Dr. VL Ratumbuysang Kota Manado. JIDAN (Jurnal Ilmiah Bidan), 2(1).33-40.

Rosdahl, Caroline Bunker dan Kowalski, Mary T. 2014. Buku Ajar Keperawatan Dasar Jakarta: EGC. 
Rizky Ayu Gardelia: The Knowledge of Pregnant Women about Pre-Eclampsia

Riwidikdo, H. 2012. Statistik Kesehatan. Yogyakarta: Nuha Madika

Sugiyono. (2017). Metode Penelitian Kuantitatif Kualitatif dan R\&D. Bandung: PT Alfabet.

Suoth, M., Bidjuni, H., \& Malara, R. (2014). Hubungan gaya hidup dengan kejadian hipertensi di puskesmas kolongan kecamatan kalawat kabupaten minahasa utara. Jurnal Keperawatan, 2(1).1-10.

Tiaranissa, A., WB, S. C., \& Sriwahyuni, E. (2016). Profil Kadar Hemoglobin pada Wanita Pre-Eklampsia Berat Dibandingkan dengan Wanita Hamil Normal. Majalah Kesehatan FKUB, 1(3), 171-177.

Yolanda, G. S. F., Mirani, P., \& Swany, S. (2015). Angka Kejadian Persalinan Preterm pada Ibu dengan Preeklampsia Berat dan Eklampsia di RSUP Dr. Mohammad Hoesin Palembang Tahun 2013. Majalah Kedokteran Sriwijaya ,47(1),31-34. 